\title{
HUBUNGAN PENGETAHUAN DAN SIKAP DENGAN PERILAKU PERAWAT DALAM PEMBUANGAN SAMPAH MEDIS DI RUMAH SAKIT PKU MUHAMMADIYAH YOGYAKARTA
}

\author{
Sudiharti, Solikhah \\ Fakultas Kesehatan Masyarakat, Universitas Ahmad Dahlan
}

\begin{abstract}
Background: Hospitals in organizing the efforts of health services will result in waste that could affect the surrounding environment, so it needs a good waste management efforts. The success of waste management is influenced by the behavior of nurses in performing particular medical waste specially. The waste management is good and right by the nurses is basically able to distinguish non-medical and medical waste. Factors knowledge and attitude is one factor in the formation of nurse behavior disposal of medical waste in hospitals. This study aims to determine the knowledge, attitudes and behavior of nurses, determine the relationship of knowledge to determine the relationship of behavior and attitudes to the behavior of nurses in medical waste disposal in PKU Muhammadiyah Hospital of Yogyakarta.

Methods: This study was an observational analytic, using cross sectional approach. The research tool was used quesionnaire. The population in this study was nurse as many as 155 people and sample as many as 60 people who were on morning shift. Analysis of the data using univariate analysis using frequency distributions and bivariate analysis using the Kendall tau correlation test.

Results: There was a relationship between the level of knowledge of the behavior of caregivers in the dump medical waste with coeffisien correlation of 0.373 with a significant value $(\rho)$ are 0.002 which indicates that the value of $(\rho)$ are smaller than the value of alpha $(\alpha)$. There was a link attitudes with behavior of nurses in the disposal of medical waste with coeffisien correlation is 0.414 with a significant value $(\rho)$ are 0.000 which indicates that the value of $(\rho)$ are smaller than the value of alpha $(\alpha)$.

Conclusion: There was a relationship between knowledge of the behavior of nurses in medical waste disposal in PKU Muhammadiyah Hospital of Yogyakarta. There was a relationship between attitudes to the behavior of nurses in medical waste disposal in PKU Muhammadiyah Hospital of Yogyakarta.
\end{abstract}

Keywords: Knowledge, Attitudes, Behavior, Medical Waste.

\section{PENDAHULUAN}

Rumah sakit merupakan bagian dari sistem pelayanan kesehatan secara keseluruhan yang menyelenggarakan kegiatan pelayanan kesehatan yang bersifat promotif (pembinaan kesehatan), preventif (pencegahan penyakit), kuratif (pengobatan penyakit) dan rehabilitatif (pemulihan kesehatan) serta dapat berfungsi sebagai tempat pendidikan tenaga kesehatan dan tempat untuk penelitian. Rumah sakit dalam menyelenggarakan upaya pelayanan rawat jalan, rawat inap, pelayanan gawat darurat, pelayanan medik, dan non medik menggunakan teknologi yang dapat mempengaruhi lingkungan sekitarnya, sehingga wajib untuk memelihara dan meningkatkan upaya penyehatan lingkungan. ${ }^{1}$

Kegiatan rumah sakit menghasilkan berbagai macam sampah yang berupa benda cair, padat dan gas. Hal ini mempunyai konsistensi perlunya pengelolaan sampah rumah sakit sebagai bagian dari kegiatan penyehatan lingkungan yang 
bertujuan untuk melindungi masyarakat dari bahaya pencemaran lingkungan yang bersumber dari sampah rumah sakit. Dampak sampah rumah sakit ini mempunyai risiko yang tinggi, infeksi virus yang serius seperti HIVIAIDS serta Hepatitis B dan $\mathrm{C}$, tenaga layanan kesehatan, terutama perawat, merupakan kelompok yang berisiko paling besar untuk terkena infeksi melalui cidera akibat benda tajam yang terkontaminasi (umumnya jarum suntik). Risiko serupa juga dihadapi tenaga kesehatan lain di rumah sakit dan pelaksana pengelolaan limbah di luar rumah sakit, begitu juga pemulung di lokasi pembuangan akhir limbah (sekalipun risiko ini tidak terdokumentasi). Di kalangan pasien dan masyarakat, risiko terkena infeksi tersebut jauh lebih rendah. Beberapa infeksi yang menyebar melalui media lain atau disebabkan oleh agen yang lebih resisten dapat menimbulkan risiko yang bermakna pada masyarakat dan pasien rumah sakit. ${ }^{2}$

Pengelolaan sampah rumah sakit semakin perlu mendapat perhatian mengingat peningkatan rumah sakit yang cukup pesat akhir-akhir ini. Berdasarkan data, di Indonesia sampai tahun 2002 terdapat sebanyak 1.215 buah rumah sakit dengan jumlah tempat tidur 130.214. Hasil kajian terhadap 100 Rumah Sakit di Jawa dan Bali menunjukkan bahwa rata-rata produksi sampah sebesar $3,2 \mathrm{~kg}$ pertempat tidur perhari. Analisa lebih jauh menunjukkan produksi sampah (Limbah Padat) berupa limbah domestik sebesar 76,8 persen dan berupa limbah infeksius sebesar 23,2 persen. Diperkirakan secara nasional produksi sampah (Limbah Padat) rumah sakit sebesar 376.089 ton per hari dan produksi air limbah sebesar 48.985,70 ton per hari. Gambaran tersebut dapat dibayangkan betapa besar potensi rumah sakit untuk mencemari lingkungan dan kemungkinan menimbulkan kecelakaan serta penularan penyakit. ${ }^{3}$

Permasalahan yang sering terjadi di rumah sakit adalah peraturan terkait kesehatan lingkungan rumah sakit masih belum memasyarakat, pelaksanaan analisis dampak lingkungan, upaya pengelolaan dan pemantauan lingkungan rumah sakit masih berorientasi secara administrasi, serta kegiatan kesehatan lingkungan rumah sakit masih belum menjadi prioritas. Salah satunya adalah pengelolaan sampah rumah sakit yang bagi orang awam mungkin terkesan berjalan apa adanya dan belum menjadi perhatian.

Faktor pengetahuan menjadi dasar keberhasilan pengelolaan sampah rumah sakit. Pengetahuan tentang pengelolaan sampah atau limbah harus dimiliki seorang Petugas Pengelola Limbah (PPL) sebagai tanggungjawab langsung kepada Direktur rumah sakit. la harus bekerja sama dengan petugas pengontrol infeksi, kepala bagian farmasi, dan teknisi radiologi agar memahami prosedur yang benar di dalam penanganan dan pembuangan limbah patologi, farmasi, kimia dan limbah radioaktif.

Keberhasilan pengelolaan sampah rumah sakit selain dilihat dari tingkat pengetahuan, ditentukan juga dari sikap. Sikap akan mempengaruhi perilaku perawat dan petugas lainnya untuk berperilaku dengan baik dan benar dalam melakukan upaya penanganan dan pembuangan sampah. Dukungan pengetahuan dan sikap ini akan berpengaruh langsung terhadap perilaku yang nyata dalam mengelola sampah.

Rumah Sakit PKU Muhammadiyah Yogyakarta merupakan rumah sakit yang telah melakukan aktifitas pengelolaan sampah padat mulai dari pemisahan, penampungan, pengangkutan dan pembuangan atau pemusnahan sehingga diharapkan sampah yang dihasilkan tidak membahayakan kesehatan masyarakat dan lingkungan. Proses pemisahan sampah di rumah sakit dilakukan oleh petugas kesehatan khususnya perawat yang berada di setiap unit pelayanan. Untuk pengolahan sampah selanjutnya dilakukan oleh petugas kebersihan di rumah sakit.

Hasil studi pendahuluan yang dilakukan peneliti di rumah sakit PKU Muhamadiyah Yogyakarta pada bulan Oktober 2011, bahwa untuk mencegah

KES MAS Vol. 6 No. 1, Januari $2012: 1$ - 74 
adanya kecelakaan kerja dan mengurangi bahaya infeksi nosokomial belum cukup dengan menyediakan pembedaan tempat sampah medis maupun non medis di ruang perawatan, karena masih sering ditemukan masalah adanya percampuran antara sampah medis dan non-medis yang dilakukan oleh perilaku perawat dalam membuang sampah. Permasalahan ini akan berpengaruh pada proses pengelolaan sampah khususnya dalam tahapan pemusnahan dan pembuangan akhir sampah. Hal ini terjadi karena kurangnya pengetahuan perawat tentang sampah, manfaat pemisahan jenis sampah sehingga menimbulkan sikap yang mempengaruhi perilaku yang tidak sesuai dengan peraturan yang telah ditetapkan. Berdasarkan uraian di atas maka penulis tertarik untuk melakukan penelitian dengan tujuan mengetahui hubungan pengetahuan dan sikap dengan perilaku perawat dalam pembuangan sampah medis di Rumah Sakit PKU Muhammadiyah Yogyakarta.

\section{METODE PENELITIAN}

Jenis penelitian ini merupakan penelitian observasional analitik dengan rancangan cross sectional. Populasi dalam penelitian ini adalah perawat yang ada di rumah sakit PKU Muhammadiyah Yogyakarta, yang berjumlah 155 orang. Sampel dalam penelitian ini adalah perawat yang sedang shif pagi yang berjumlah 60 orang. Berdasarkan data distribusi perawat per ruang di RS PKU Muhammadiyah Yogyakarta, maka penentuan pengambilan sampel dalam penelitian ini dilakukan dengan 2 (dua) tahap, yaitu pengambilan sampel secara purposive sampling dan Pengambilan sampel secara acak sederhana (simple random sampling). Analisis data dilakukan dengan menggunakan analisis univariat dan analisis bivariat. Lokasi penelitian dilakukan di Rumah Sakit PKU Muhamadiyah Yogyakarta, Jalan K.H Ahmad Dahlan No. 20 Yogyakarta. Penelitian dilakukan pada bulan Desember 2011.

\section{HASIL PENELITIAN DAN PEMBAHASAN}

\section{A. Hasil Penelitian}

1) Profil dan Sejarah Rumah Sakit PKU Muhammadiyah Yogyakarta

Rumah sakit umum PKU Muhammadiyah Yogyakarta awalnya didirikan berupa klinik dan poliklinik pada tanggal 15 Februari 1923 lokasi pertama di Kampung Jagang Notoprajan Yogyakarta. Awalnya bernama PKO (Penolong Kesengsaraan Oemoum). Diselenggarakan oleh Perserikatan Muhammadiyah dalam rangka menolong kaum duafa, khususnya yang sedang sakit dan tidak mampu berobat. Didirikan atas inisiatif H.M Sudjak yang di dukung sepenuhnya oleh K.H Ahmad Dahlan. Seiring dengan waktu, nama PKO berubah menjadi PKU (Pembina Kesejahteraan Umat). 
2) Karakteristik Responden

a ) Karakteristik Perawat Berdasarkan Jenis Kelamin

Tabel 1. Distribusi Frekuensi Perawat Berdasarkan Jenis Kelamin di Rumah Sakit PKU Muhammadiyah Yogyakarta 2011

\begin{tabular}{llcc}
\hline No. & Jenis Kelamin & Frekuensi (F) & Persentase (\%) \\
\hline 1. & Perempuan & 48 & 80 \\
\hline 2. & Laki-laki & 12 & 20 \\
\hline & Total & 60 & 100
\end{tabular}

Berdasarkan tabel 3 di atas menunjukkan bahwa mayoritas responden berjenis kelamin perempuan yaitu $80 \%$ dan yang berjenis kelamin laki-laki yaitu $20 \%$.

b) Karakteristik Perawat Berdasarkan Umur

Tabel 4. Distribusi Frekuensi Perawat Berdasarkan Umur di Rumah Sakit PKU Muhammadiyah Yogyakarta 2011

\begin{tabular}{cccc}
\hline No. & Umur (Tahun) & Frekuensi (F) & Persentase $(\%)$ \\
\hline 1. & $20-25$ & 6 & 10 \\
\hline 2. & $26-30$ & 7 & 11,67 \\
\hline 3. & $31-35$ & 14 & 23,33 \\
\hline 4. & $36-40$ & 30 & 50 \\
\hline 5. & $>40$ & 3 & 5 \\
\hline & Total & 60 & 100
\end{tabular}

Berdasarkan tabel 4 di atas menunjukkan bahwa mayoritas responden berumur 36-40 yaitu sebesar $50 \%$ sedangkan kelompok usia terendah adalah $>40$ yaitu $5 \%$.

c) Karakter Responden Berdasarkan Tingkat Pendidikan

Tabel 5. Distribusi Frekuensi Perawat berdasarkan Tingkat Pendidikan di Rumah Sakit PKU Muhammadiyah Yogyakarta 2011

\begin{tabular}{|c|c|c|c|}
\hline No. & Pendidikan & Frekuensi $(\mathrm{F})$ & Persentase (\%) \\
\hline 1. & SPK & 6 & 10 \\
\hline 2. & D 3 & 36 & 60 \\
\hline 3. & S 1 & 18 & 30 \\
\hline & Total & 60 & 100 \\
\hline
\end{tabular}

Berdasarkan tabel 5 menunjukkan bahwa sebagian besar responden mempunyai latar belakang pendidikan D3 yaitu 60\% (36 responden), sedangkan perawat dengan latar belakang pendidikan S1 yaitu $30 \%$ (18 responden). 
d) Karakteristik Responden Berdasarkan Masa Kerja

Tabel 6. Distribusi Frekuensi Perawat Berdasarkan Masa Kerja di Rumah Sakit PKU Muhammadiyah Yogyakarta 2011

\begin{tabular}{|c|c|c|c|}
\hline No. & Masa Kerja & Frekuensi (F) & Persentase (\%) \\
\hline 1. & $1-5$ & 12 & 20 \\
\hline 2. & $6-10$ & 8 & 13,33 \\
\hline 3. & $11-15$ & 25 & 41,67 \\
\hline 4. & $>16$ & 15 & 25 \\
\hline & Total & 60 & 100 \\
\hline
\end{tabular}

Berdasarkan tabel 6 menunjukkan bahwa sebagian besar masa kerja responden adalah 11-15 tahun yaitu $41,67 \%$ (25 responden), sedangkan responden dengan masa kerja 6-10 tahun hanya berjumlah $13,33 \%$ (8 responden).

\section{B. Analisis Univariat}

1) Tingkat Pengetahuan Perawat dalam Pembuangan Sampah Medis di Rumah Sakit PKU Muhammadiyah Yogyakarta

Tabel 7. Gambaran Umum Frekuensi Pengetahuan Perawat dalam Pembuangan Sampah Medis di Rumah Sakit PKU Muhammadiyah Yogyakarta 2011

\begin{tabular}{cccc}
\hline No. & $\begin{array}{c}\text { Pengetahuan Perawat } \\
\text { dalam Pembuangan } \\
\text { Sampah }\end{array}$ & Frekuensi (F) & Persentase (\%) \\
\hline 1. & Baik & 21 & 35 \\
\hline 2. & Cukup & 30 & 50 \\
\hline 3. & Kurang & 9 & 15 \\
\hline & Total & 60 & 100 \\
\hline
\end{tabular}

Berdasarkan tabel 7 diperoleh data dari 60 responden, terdapat 21 perawat $(35 \%)$ yang mempunyai pengetahuan baik, 30 perawat $(50 \%)$ mempunyai pengetahuan cukup dan 9 perawat (15\%) mempunyai pengetahuan yang kurang.

2) Sikap Perawat dalam Pembuangan Sampah Medis di Rumah Sakit PKU Muhammadiyah Yogyakarta

Tabel 8. Gambaran Umum Frekuensi Sikap Perawat dalam Pembuangan Sampah Medis di Rumah Sakit PKU Muhammadiyah Yogyakarta 2011

\begin{tabular}{llcc}
\hline No. & $\begin{array}{c}\text { Sikap Perawat dalam } \\
\text { Pembuangan Sampah }\end{array}$ & Frekuensi $(\mathrm{F})$ & Persentase $(\%)$ \\
\hline 1. & Baik & 22 & 36,67 \\
\hline 2. & Cukup & 26 & 43,33 \\
\hline 3. & Kurang & 12 & 20 \\
\hline & Total & 60 & 100 \\
\hline
\end{tabular}

Berdasarkan tabel 8 diperoleh data dari 60 responden terdapat 22 perawat $(36,67 \%)$ mempunyai sikap yang baik, 26 perawat $(43,33 \%)$ mempunyai sikap cukup dan 12 perawat (20\%) mempunyai sikap kurang. 
3) Perilaku Perawat dalam Pembuangan Sampah Medis di Rumah Sakit PKU Muhammadiyah Yogyakarta

Tabel 9. Gambaran Umum Frekuensi Perilaku dalam Pembuangan Sampah Medis di Rumah Sakit PKU Muhammadiyah Yogyakarta 2011

\begin{tabular}{llcc}
\hline No. & $\begin{array}{c}\text { Perilaku Perawat } \\
\text { dalam Pembuangan } \\
\text { Sampah }\end{array}$ & Frekuensi (F) & Persentase (\%) \\
\hline 1. & Baik & 15 & 25 \\
\hline 2. & Cukup & 28 & 46,67 \\
\hline 3. & Kurang & 17 & 28,33 \\
\hline & Total & 60 & 100 \\
\hline
\end{tabular}

Berdasarkan tabel 9 diperoleh data dari 60 responden terdapat 15 perawat $(25 \%)$ mempunyai perilaku yang baik dalam proses pembuangan sampah medis, 28 perawat $(46,67 \%)$ mempunyai perilaku cukup dan 17 perawat $(28,33 \%)$ mempunyai perilaku kurang.

\section{Analisis Bivariat}

1) Hubungan Pengetahuan dengan Perilaku Perawat dalam Pembuangan Sampah Medis di Rumah Sakit PKU Muhammadiyah Yogyakarta

Tabel 10. Hubungan Pengetahuan dengan Perilaku Perawat dalam Pembuangan Sampah di Rumah Sakit PKU Muhammadiyah Yogyakarta 2011

\begin{tabular}{|c|c|c|c|}
\hline \multicolumn{4}{|c|}{ Correlations } \\
\hline & & $\begin{array}{c}\text { pengetahuan } \\
\text { perawat }\end{array}$ & $\begin{array}{l}\text { perilaku } \\
\text { perawat }\end{array}$ \\
\hline \multirow[t]{6}{*}{ Kendall's tau_b pengetahuan per } & Correlation Coefficier & 1.000 & $.373^{* \star}$ \\
\hline & Sig. (2-tailed) & & .002 \\
\hline & $\mathrm{N}$ & 60 & 60 \\
\hline & Correlation Coefficier & $.373^{* *}$ & 1.000 \\
\hline & Sig. (2-tailed) & .002 & \\
\hline & $\mathrm{N}$ & 60 & 60 \\
\hline
\end{tabular}

${ }^{* *}$. Correlation is significant at the 0.01 level (2-tailed).

Berdasarkan tabel uji statistik di atas diperoleh correlation coeffisien yaitu 0,373 dengan nilai Signifikan $(\rho)$ yaitu 0,002 yang menunjukan bahwa nilai $\rho<0,05$. Hal ini berarti terdapat hubungan yang kuat dan positif antara tingkat pengetahuan dengan perilaku perawat dalam pembuangan sampah medis di rumah sakit PKU Muhammadiyah Yogyakarta. Nilai $r$ mempunyai makna bahwa pengetahuan memberikan kontribusi terhadap kejadian perilaku perawat dalam pembuangan sampah medis sebesar 0,373 atau $37,3 \%$. 
2) Sikap dengan Perilaku Perawat dalam Pembuangan Sampah Medis di Rumah Sakit PKU Muhammadiyah Yogyakarta

Tabel 11. Hubungan Sikap dengan Perilaku Perawat dalam Pembuangan Sampah di RS PKU Muhammadiyah Yogyakarta 2011

Correlations

\begin{tabular}{|c|c|c|c|c|}
\hline & & & sikap perawat & $\begin{array}{l}\text { perilaku } \\
\text { perawat }\end{array}$ \\
\hline \multirow[t]{6}{*}{ Kendall's tau_b } & \multirow[t]{3}{*}{ sikap perawat } & Correlation Coefficient & 1.000 & $.414^{\star \star}$ \\
\hline & & Sig. (2-tailed) & & .000 \\
\hline & & $\mathrm{N}$ & 60 & 60 \\
\hline & \multirow[t]{3}{*}{ perilaku perawat } & Correlation Coefficient & $.414^{* *}$ & 1.000 \\
\hline & & Sig. (2-tailed) & .000 & . \\
\hline & & $\mathrm{N}$ & 60 & 60 \\
\hline
\end{tabular}

${ }^{\star *}$. Correlation is significant at the 0.01 level (2-tailed).

Berdasarkan tabel uji statistik di atas diperoleh correlation coeffisien yaitu 0,414 dengan nilai Signifikan $(\rho)$ yaitu 0,000 yang menunjukan bahwa nilai $\rho<0,05$. Hal ini berarti terdapat hubungan yang kuat dan positif antara sikap dengan perilaku perawat dalam pembuangan sampah medis di rumah sakit PKU Muhammadiyah Yogyakarta. Nilai $r$ mempunyai makna bahwa sikap memberikan kontribusi terhadap kejadian perilaku perawat dalam pembuangan sampah medis sebesar 0,414 atau $41,4 \%$.

\section{Pembahasan}

\section{1) Pengetahuan}

Berdasarkan hasil analisis univariat menunjukan bahwa dari 60 perawat yang ada di rumah sakit PKU Muhammadiyah Yogyakarta yang sedang shif pagi, sebagian besar memiliki pengetahuan yang cukup sebanyak 30 orang atau (50\%). Hal ini menunjukan bahwa pengetahuan yang dimiliki perawat tentang sampah, jenis sampah, cara pembuangan sampah medis masih kurang. Perawat belum mampu melakukan pemilahan sampah dengan baik. masih ada sampah non medis masuk ke tempat sampah medis, demikian sebaliknya dan banyak perawat pada saat membuang sampah kurang memperhatikan warna kantung sampah yang sudah disediakan oleh pihak pengelola sampah. Hal ini dapat menimbulkan kecelakaan kerja pada petugas pengelola sampah, maupun petugas kesehatan lainnya.

Faktor pengetahuan tentang sampah sangat penting untuk ditanamkan pada setiap perawat yang akan melakukan pembuangan sampah rumah sakit. Salah satu upaya untuk meningkatkan pengetahuan dengan memberikan pelatihan atau penyuluhan sebagai sarana pemberian pendidikan khususnya perawat untuk berperilaku membuang sampah medis sesuai dengan tempatnya. sehingga dapat mengurangi dampak terjadinya kecelakaan kerja maupun infeksi nosokomial.

Pengetahuan merupakan hasil dari tahu, dan ini terjadi setelah orang melakukan pengindraan terhadap suatu objek tertentu. Pengindraan terjadi melalui pancaindra manusia, yakni indra penglihatan, pendengaran, penciuman, perasa dan peraba. Sebagian besar pengetahuan manusia diperoleh melalui mata dan telinga. Pengetahuan merupakan domain yang 
sangat penting dalam membentuk tindakan seseorang. ${ }^{4}$

Menurut Asrini dkk (2007) ${ }^{5}$ faktor yang mempengaruhi pengetahuan dalam masyarakat yaitu: 1) sosial ekonomi, 2) kultur (budaya dan agama), 3) pendidikan, dan 4) pengalaman. Perilaku yang didasari oleh pengetahuan akan bersifat langgeng. Pengetahuan dibagi menjadi enam tahap yaitu tahu, memahami penerapan analisis, sintesis, dan evaluasi, sehingga dapat dipahami bahwa untuk membentuk perilaku yang baik harus mencapai tingkat penerapan.

Menurut Bahtiar dkk $(2008)^{6}$ pengetahuan terbentuk dengan dipengaruhi oleh beberapa faktor yang dapat digolongkan menjadi dua bagian yaitu faktor internal dan eksternal. Faktor internal antara lain yaitu umur dan intelegensi sedangkan faktor eksternal yaitu pendidikan, lingkungan, pengalaman, informasi, dan orang yang dianggap penting. Pendidikan sebagai faktor eksternal pembentuk pengetahuan dengan melihat hasil penelitian bahwa tingkat pengetahuan perawat dalam melakukan pembuangan sampah medis sebagian besar adalah cukup yaitu $60 \%$ dari lulusan D3, dibandingkan dengan yang lulusan sarjana yaitu $30 \%$. Semakin rendah pendidikan seseorang maka akan menghambat perkembangan sikap seseorang terhadap penerimaan, informasi dan nilainilai yang baru diperkenalkannya. Sebaliknya semakin tinggi pendidikan seseorang maka semakin mudah menerima informasi, dan pada akhirnya makin banyak pula pengetahuan yang dimilikinya.

Faktor internal yang mempengaruhi pengetahuan yaitu umur, dimana seseorang semakin bertambah umurnya, maka akan berkurang daya penangkapan informasinya. Hal ini terbukti dalam penelitian ini bahwa responden dengan umur 36-40 jauh lebih banyak yaitu 50\% dibandingkan dengan responden yang berumur $20-25$ yaitu $10 \%$. Hal ini menandakan bahwa faktor pembentuk pengetahuan baik internal maupun eksternal berpengaruh terhadap tingkat pengetahuan seseorang.

\section{2) Sikap}

Berdasarkan hasil analisis univariat menunjukan bahwa dari 60 perawat yang ada di rumah sakit PKU Muhammadiyah Yogyakarta yang sedang shif pagi, sebagian besar memiliki sikap yang cukup sebanyak 26 orang $(43,3 \%)$, yang memiliki sikap baik yaitu 22 orang $(36,67 \%)$. Hasil observasi di lapangan masih sering terjadi adanya percampuran antara sampah medis dan non medis yang dilakukan oleh perawat. Kesediaan perawat dalam kepeduliaanya membuang sampah medis di rumah sakit tidak dilakukan secara baik. Hal ini dipengaruhi kurangnya perawat untuk memperhatikan spesifikasi tempat pembuangan sampah. bahaya yang ditimbulkan dari sampah dan tidak adanya pengawasan khusus dari petugas pengelola sampah.

Upaya pengelola sampah yang dapat mempengaruhi sikap seorang perawat dalam melakukan pembuangan sampah medis diharapkan adanya pengawasan maupun peneguran jika terjadi sikap yang salah dan adanya petugas yang melakukan pengecekan keadaan sampah di setiap ruangan agar tidak terjadi penumpukan sampah. Sikap akan berdampak pada perilaku setiap perawat, dengan sikap yang baik diharapkan akan menimbulkan perilaku yang baik walaupun tidak selalu.

Sikap merupakan reaksi atau respon yang masih tertutup dari seseorang terhadap suatu stimulus atau objek. Sikap belum merupakan suatu tindakan atau aktivitas, akan tetapi merupakan predisposisi tindakan 
suatu perilaku. Sikap ini masih merupakan reaksi tertutup, bukan merupakan reaksi terbuka atau tingkah laku yang terbuka (Asrini dkk, 2007). ${ }^{6}$ Sikap seseorang terbentuk dalam suatu objek dalam hal ini tentang perawat dalam pembuangan sampah medis dipengaruhi oleh beberapa hal yaitu pengalaman pribadi, lingkungan, kebudayaan, media massa, dan lembaga pendidikan dan agama. ${ }^{7}$

Hasil ini selaras dengan penelitian Irawansyah $(2009)^{8}$ tentang hubungan pengetahuan dan sikap dengan perilaku penjamah makanan dalam mengelola makanan di instalasi gizi RSUD Panembahan Senopati Bantul, hasil penelitiannya tentang sikap mengatakan bahwa 54,5\% (18 responden) memiliki sikap yang cukup dan sebanyak 45,5\% (15 responden) memiliki sikap yang baik.

\section{3) Perilaku Perawat dalam Pembuangan Sampah}

Berdasarkan hasil analisis univariat menunjukan bahwa dari 60 perawat yang ada di rumah sakit PKU Muhammadiyah Yogyakarta yang sedang shif pagi, sebagian besar memiliki perilaku yang cukup sebanyak 28 orang $(46,7 \%)$ dan yang memiliki perilaku baik sebanyak 15 orang (25\%). Hal ini menggambarkan perilaku yang dilakukan oleh perawat dalam membuang sampah medis belum sesuai dengan peraturan yang telah ditetapkan oleh pihak rumah sakit. Pihak rumah sakit dalam hal ini adalah pihak pengelola sampah yaitu kepala sanitasi, dimana telah menyediakan tempat sampah yang telah dilengkapi dengan poster atau slogan tentang aturan dalam melakukan pembuangan sampah, namun hal ini kurang diperhatikan oleh perawat dalam membuang sampah.

Berdasarkan observasi atau pengalaman langsung terhadap perilaku responden dimana masih ada perawat dalam membuang sampah tidak disesuaikan dengan tempatnya, seperti sampah infeksius di buang di tempat sampah umum, demikian sebaliknya. Hal ini dipengaruhi oleh perilaku perawat yang hanya memperhatikan jarak terdekat tanpa memperhatikan spesifikasi tempat pembuangan sampah yang benar. Faktor pengetahuan dan sikap merupakan faktor domain terjadinya perilaku, maka upaya adanya pelatihan, pengawasan, peneguran, maupun menyediakan sarana dan prasarana dalam hal ini menambah jumlah tempat sampah merupakan beberapa upaya untuk memperbaiki perilaku perawat dalam mengelola sampah di rumah sakit khususnya sampah medis.

Komponen perilaku dalam struktur bersikap menunjukan bagaimana kecenderungan berperilaku yang ada dalam diri seseorang berkaitan dengan objek sikap yang dihadapinya. Perubahan perilaku yang terjadi dalam diri seseorang dapat diketahui melalui persepsi, akan tetapi setiap orang mempunyai persepsi yang berbeda, meskipun mengamati objek yang sama. Perubahan perilaku pada orang dewasa akan lebih sulit karena orang dewasa sudah mempunyai sikap, pengetahuan dan keterampilan tertentu yang mungkin sudah dimiliki bertahun-tahun. Adanya pengetahuan, sikap dan perilaku baru yang belum mereka yakini akan sulit diterima, untuk itu perlu dilakukan usaha tersendiri agar subjek belajar meyakini pentingnya pengetahuan, sikap dan perilaku tersebut. ${ }^{6}$ Hasil penelitian ini selaras dengan penelitian Irawansyah $(2009)^{8}$ hasil penelitiannya tentang perilaku mengatakan bahwa sebanyak $57,5 \%$ (19 responden) memiliki perilaku cukup dan sebanyak 42,4\% (14 responden) memiliki perilaku baik. 
4) Hubungan Tingkat Pengetahuan dengan Perilaku Perawat dalam Pembuangan Sampah Medis di Rumah Sakit

Hasil penelitian menunjukan bahwa terdapat hubungan antara pengetahuan dengan perilaku perawat dalam pembuangan sampah. Hal ini dibuktikan dengan hasil uji statistik Kendall's Tau diperoleh correlation coeffisien yaitu 0,373 dengan nilai Signifikan $(\rho)$ yaitu 0,002 yang menunjukan bahwa nilai $\rho<0,05$. Hal ini berarti terdapat hubungan yang kuat dan positif antara tingkat pengetahuan tentang sampah dengan perilaku dalam membuang sampah medis di rumah sakit PKU Muhammadiyah Yogyakarta. Nilai $r$ mempunyai makna bahwa pengetahuan memberikan kontribusi terhadap kejadian perilaku perawat dalam pembuangan sampah medis sebesar 0,373 atau $37,3 \%$. Hal ini didukung oleh peneliti terdahulu yaitu hasil penelitian Irawansyah $(2009)^{10}$ dengan nilai $p=0,000$, dengan $\mathrm{R}=0,659$, dan Rsquare $=0,593$ artinya ada hubungan yang signifikan antara pengetahuan dengan perilaku.

Pengetahuan perawat merupakan salah satu faktor predisposisi suatu perilaku. Pengetahuan perawat dapat terus meningkat apabila pihak rumah sakit dapat terus meningkatkan kemampuan perawat dengan mengadakan berbagai pelatihan pada semua karyawan khususnya perawat pada aspek pengelolaan sampah medis di Rumah Sakit PKU Muhammadiyah Yogyakarta.

\section{5) Hubungan Sikap dengan Perilaku Perawat dalam Pembuangan Sampah Medis di Rumah Sakit}

Hasil penelitian menunjukan diperoleh correlation coeffisien yaitu 0,414 dengan nilai Signifikan $(\rho)$. yaitu 0,000 yang menunjukan bahwa nilai $\rho<0,05$. Hal ini berarti terdapat hubungan yang kuat dan positif antara sikap dengan perilaku dalam membuang sampah medis di rumah sakit PKU Muhammadiyah Yogyakarta. Nilai $r$ mempunyai arti bahwa sikap memberikan kontribusi terhadap kejadian perilaku perawat dalam pembuangan sampah medis sebesar 0,414 atau $41,4 \%$. Hal ini didukung oleh peneliti terdahulu yaitu hasil penelitian Irawansyah (2009) bahwa ada hubungan antara pengetahuan dengan perilaku dengan nilai $p=0,000$, dengan $R=0,770$, dan Rsquare $=0,593$ artinya ada hubungan yang signifikan antara pengetahuan dengan perilaku.

\section{SIMPULAN DAN SARAN}

\section{A. Simpulan}

1) Ada hubungan antara tingkat pengetahuan dengan perilaku perawat dalam pembuangan sampah medis di rumah sakit PKU Muhammadiyah Yogyakarta.

2) Ada hubungan antara sikap dengan perilaku perawat dalam pembuangan sampah medis di rumah sakit PKU Muhammadiyah Yogyakarta. 


\section{B. Saran}

1) Bagi Pimpinan Unit Sanitasi di rumah sakit PKU Muhammadiyah Yogyakarta di harapkan untuk memberikan peringatan kepada perawat yang diketahui telah membuang sampah yang tidak sesuai dengan tempat yang telah disediakan di rumah sakit PKU Muhammadiyah Yogyakarta.

2) Bagi manajemen rumah sakit PKU Muhammadiyah Yogyakarta diharapkan mengadakan pelatihan tentang pembuangan sampah medis dan non medis yang lebih intensif minimal 1 tahun 2 kali sehingga dapat meningkatkan pengetahuan perawat tentang pembuangan sampah khususnya sampah medis.

3) Bagi peneliti selanjutnya khususnya mahasiswa fakultas kesehatan masyarakat diharapkan dapat meneliti variabel yang lain seperti sarana dan prasarana, umur, masa kerja dan lain-lain, yang berhubungan dengan perilaku dan dengan jumlah sampel yang lebih banyak sehingga dapat diperoleh data yang lebih lengkap

\section{DAFTAR PUSTAKA}

1. Adisasmito, W., Sistem Manajemen Lingkungan Rumah Sakit, Hal. 2-3, Grafindo Persada, Jakarta. 2007

2. WHO, Pengelolaan Aman Limbah Layanan Kesehatan, Hal. 25, Penerbit Buku Kedokteran, EGC, Jakarta. 2005

3. Depkes RI, Pedoman Teknis Pengelolaan Limbah Klinis, Desinfeksi dan Strelisasi di Rumah Sakit, Direktorat Jenderal Pemberantasan Penyakit Menular dan Penyehatan Lingkungan, Depkes RI, Jakarta. 1997

4. Notoatmodjo, S., Promosi Kesehatan dan IImu Perilaku, Hal. 133-188, Rineka Cipta, Jakarta. 2007

5. Asrini N.Y., Akhmadi, Harjanto D., "Hubungan Pengetahuan, Sikap dan Perilaku Masyarakat tentang Kegiatan 3M dengan Angka Bebas Jentik", Jurnal IImu Keperawatan, Vol 2 Nomor 2. 2007

6. Bachtiar A., Milwati S., Nisfadhila C., "Hubungan Tingkat Pengetahuan Agama Islam dengan Sikap Perilaku Seks Remaja di Madrasah Aliyah Negeri III Malang", Jurnal Kesehatan Volume 6/no.1/2008:23-32. 2008

7. Azwar, S., Sikap Manusia Teori dan Pengukurannya, Hal.5-30, Pustaka Pelajar, Jakarta. 1995

8. Irawansyah, Hubungan Pengetahuan, Sikap dengan Perilaku Penjamah Makanan dalam Mengelola Makanan di Instalasi Gizi RSUD Panembahan Senopati Bantul, Skripsi, Fakultas Kesehatan Masyarakat, Universitas Ahmad Dahlan, Yogyakarta. 2009 